\title{
High-Throughput rRNA Gene Sequencing Reveals High and Complex Bacterial Diversity Associated with Brazilian Coffee Bean Fermentation
}

\section{Dão Pedro de Carvalho Neto, Gilberto Vinícius de Melo Pereira, Júlio César de Carvalho, Vanete Thomaz Soccol and Carlos Ricardo Soccol*}

Bioprocess Engineering and Biotechnology Department Federal University of Paraná Curitiba, PR 81531-980, Brazil

Received: July 27, 2017 Accepted: December 6, 2017

\footnotetext{
${ }^{*}$ Corresponding author:

Phone: +554133613191 ;

Fax: +554133613695 ;

E-mail: soccol@ufpr.br
}

ORCID IDs: 0000-0002-7164-2196 (de Carvalho Neto), 0000-0001-7671-8682 (de Melo Pereira), 0000-0001-7558-7748 (de Carvalho), 0000-0001-9301-541X (Soccol, VT), 0000-0001-7630-6864 (Soccol, RC)

Paper was presented at the 7th International Forum on Industrial Bioprocessing - IFIBiop 2017, May 21-24, 2017, Wuxi, PR China

\section{SUMMARY}

Coffee bean fermentation is a spontaneous, on-farm process involving the action of different microbial groups, including bacteria and fungi. In this study, high-throughput sequencing approach was employed to study the diversity and dynamics of bacteria associated with Brazilian coffee bean fermentation. The total DNA from fermenting coffee samples was extracted at different time points, and the $16 \mathrm{~S}$ rRNA gene with segments around the V4 variable region was sequenced by Illumina high-throughput platform. Using this approach, the presence of over eighty bacterial genera was determined, many of which have been detected for the first time during coffee bean fermentation, including Fructobacillus, Pseudonocardia, Pedobacter, Sphingomonas and Hymenobacter. The presence of Fructobacillus suggests an influence of these bacteria on fructose metabolism during coffee fermentation. Temporal analysis showed a strong dominance of lactic acid bacteria with over $97 \%$ of read sequences at the end of fermentation, mainly represented by the Leuconostoc and Lactococcus. Metabolism of lactic acid bacteria was associated with the high formation of lactic acid during fermentation, as determined by HPLC analysis. The results reported in this study confirm the underestimation of bacterial diversity associated with coffee fermentation. New microbial groups reported in this study may be explored as functional starter cultures for on-farm coffee processing.

Key words: lactic acid bacteria, coffee fermentation, bacterial dynamics, Fructobacillus sp.

\section{INTRODUCTION}

Coffee is one of the most appreciated beverages in the world, with a consumption of more than 500 billion coffee cups per year. Surpassing a global production of 9 million tonnes, the coffee now stands as the second largest commodity in market value, after only petroleum (1). With an annual output of 3.02 million tonnes, Brazil is the main producer and exporter of coffee beans, followed by Vietnam, Colombia, Indonesia, Ethiopia, India and Honduras (2).

Coffee beans, unlike other fermented foods, require fermentation to facilitate the drying process. After harvesting and pulping, the residual mucilaginous layer that surrounds the coffee beans can be eliminated through microbial fermentation. This involves the action of complex microbial interactions, led mainly by yeasts (e.g. Pichia guilliermondii, P. anomala, Kluyveromyces marxianus and Saccharomyces cerevisae) and lactic acid bacteria (e.g. Erwinia herbicola, Klebsiella pneumoniae and Lactobacillus brevis) (3-5). These fermentation organisms utilize the bean pulp as a carbon and nitrogen source and produce significant amounts of ethanol, lactic acid and other microbial metabolites, resulting in lowered pH (from 5.5-6.0 to 3.5-4.0) (6,7). In addition, some of these microbial metabolites, which are precursors of volatile compounds formed during roasting, help in improving beverage flavour $(7,8)$.

Culture-independent techniques have helped to change the way to study food microbial ecology, leading to consideration of microbial populations as consortia (9). The advent of the use of molecular techniques and, more specifically, the use of high-throughput 
sequencing (HTS), permitted to overcome the limitations of the cultivation-associated methods, allowing a breakthrough in understanding the diversity and composition of several food microbial ecosystems (10-13). Illumina MiSeq ${ }^{\circledR}$ (Illumina Inc, San Diego, CA, USA) generates shorter reads (250 bp) than other HTS systems but gives a higher throughput, providing thousands of high-quality reads of the generated amplicons and allowing a superior taxonomical analysis (14).

In this work, we report a diversity analysis aiming to characterize bacterial communities associated with coffee bean fermentation, using high-throughput sequencing, as part of a whole metagenome study of the microbiota associated with the Brazilian coffee processing chain.

\section{MATERIALS AND METHODS}

\section{On-farm coffee fermentation and sampling}

Spontaneous fermentations were performed at the Fazenda Apucarana located in the Cerrado Mineiro region (18 ${ }^{\circ} 55^{\prime} 59.4^{\prime \prime}$ S, 46 50'41.5" W) at Minas Gerais, Brazil. Freshly harvested coffee (Coffea arabica var. Catuaí) cherries were depulped using a BDSV-04 depulper (Pinhalense, São Paulo, Brazil) obtaining beans with a surrounding layer of mucilage (15). Fermentations were conducted for $24 \mathrm{~h}$ in cement tanks with a nominal volume of $4.5 \mathrm{~m}^{3}$, containing $20 \mathrm{~kg}$ of depulped beans and approx. $500 \mathrm{~L}$ of fresh water, in accordance with the local wet processing method. At the end of the process, fermented beans were sun-dried for 20 days to 11-12 $\%$ moisture, as measured by a moisture meter (model AL-102 ECO; Agrologic, São Leopoldo, Brazil). Environmental temperature during the experimental procedure was $24-32{ }^{\circ} \mathrm{C}$ (day) and $12-15^{\circ} \mathrm{C}$ (night). Samples (fermenting coffee bean pulp mass) were collected at random at 0, 12 and $24 \mathrm{~h}$ for HTS and target metabolic analysis.

\section{Total DNA extraction}

For extraction of total DNA from the samples, $1 \mathrm{~mL}$ of coffee bean pulp mass was centrifuged at $12000 \times \mathrm{g}$ for 1 min (centrifuge model 5430; Eppendorf, Hamburg, Germany). Cell pellet was resuspended in $500 \mu \mathrm{L}$ of Tris-EDTA, homogenized with $10 \mu \mathrm{L}$ of lysozyme solution $(20 \mathrm{mg} / \mathrm{mL}$; Sigma-Aldrich, Arklow, Ireland) and incubated at $30^{\circ} \mathrm{C}$ for 60 min. Then, $50 \mu \mathrm{L}$ of sodium dodecyl sulphate (SDS; $10 \%$, by mass per volume) and $10 \mu \mathrm{L}$ of proteinase $\mathrm{K}$ solution at $20 \mathrm{mg} / \mathrm{mL}$ (Sigma-Aldrich) were added to the lysis solution, followed by homogenization and incubation at $60^{\circ} \mathrm{C}$ for 60 min. A volume of $150 \mu \mathrm{L}$ of phenol/chloroform (25:24; Sigma-Aldrich) was added, homogenized by inversion and centrifuged at $12000 \times g$ (model 5430R; Eppendorf) for $5 \mathrm{~min}$. Supernatant was removed and the DNA was precipitated with $3 \times$ (by volume) absolute ethanol (Sigma-Aldrich). Pellets was washed with $80 \%$ ethanol, dried and resuspended in Mili- $Q^{\circledR}$ ultrapure water (Merck, Kenilworth, NJ, USA). Total DNA was quantified with the Nanodrop 2000 instrument (Thermo Fisher Scientific, Inc., Waltham, MA, USA).

\section{Illumina high-throughput sequencing}

A fragment of the 16S rRNA gene was amplified from the total DNA extracted using primers for the $\mathrm{V} 4$ region (bases 515 to 806), containing complementary adaptors for Illumina platform (16) using KlenTAQ polymerase (Sigma-Aldrich). Amplification was performed using the degenerated primers 515F (5'-GTGCCAGCMGCCGCGGTAA-3') and 806R (5'-GGACTACHVGGGTWTCTAAT- $3^{\prime}$ ), where $M$ is $A / C, H$ is $A / C / T, V$ is $A / C / G$ and $W$ is $A / T$ (17). Bar-coded amplicons were generated by PCR under the following conditions: $95^{\circ} \mathrm{C}$ for $3 \mathrm{~min}$, followed by 18 cycles at $95^{\circ} \mathrm{C}$ for $30 \mathrm{~s}$, annealing at $50^{\circ} \mathrm{C}$ for $30 \mathrm{~s}$, extension at $68^{\circ} \mathrm{C}$ for $60 \mathrm{~s}$, and final extension at $68^{\circ} \mathrm{C}$ for $10 \mathrm{~min}$. Samples were sequenced in the MiSeq (Illumina Inc) platform using 500 V2 kit (Illumina Inc), following standard Illumina protocols.

\section{Bioinformatics and data analysis}

Data generated by sequencing went through a rigorous quality system that involved: (i) identification and removal of sequences containing more than one ambiguous base $(\mathrm{N})$, and (ii) evaluation of the presence and complementarity of primer and barcode sequences. Chimeric sequence detection, removal of noises from pre-cluster and taxonomic attribution were also performed using standard parameters of QIIME (Quantitative Insights Into Microbial Ecology) software package, v. 1.9.0 (17). Applying the UCLUST method (18), sequences presenting identity above $97 \%$ were considered the same operational taxonomic units (OTUs) according to the SILVA database (19).

\section{High-performance liquid chromatography}

The concentration of reducing sugars (glucose and fructose), organic acids (acetic, succinic, lactic and propionic acids) and ethanol was determined during coffee bean fermentation by high-performance liquid chromatography (HPLC). Samples were centrifuged at $6000 \times g$ (centrifuge model CT-6000; Cientec, Porto Alegre, Brazil) and filtered through 0.22- $\mu \mathrm{m}$ pore size filter (Sartorius Stedim, Goettingen, Germany) in order to remove debris. Analysis parameters were determined according to de Carvalho Neto et al. (20). Filtered samples were injected into HPLC system equipped with an Aminex HPX 87 H column (300 mm×7.8 mm; Bio-Rad, Richmond, CA, USA) and a refractive index (RI) detector (model HPG1362A; Hewlett-Packard Company, São Paulo, Brazil). The column was eluted in isocratic mode with a mobile phase of $5 \mathrm{mM} \mathrm{H}_{2} \mathrm{SO}_{4}$ at $60^{\circ} \mathrm{C}$ and a flow rate of $0.6 \mathrm{~mL} \cdot \mathrm{min}$.

\section{RESULTS AND DISCUSSION}

\section{Sugar consumption and metabolite formation}

Table 1 shows the evolution of sugar consumption, metabolite formation and $\mathrm{pH}$ decrease during fermentation of coffee bean pulp. The observed increase in the concentration of reducing sugars (glucose and fructose) at $12 \mathrm{~h}$ of 
fermentation can be attributed to the hydrolysis of sucrose by the action of yeast invertase (21). These sugars were partially consumed after $24 \mathrm{~h}$ of fermentation, with a final residual content of 3.2 and $4.5 \mathrm{~g} / \mathrm{L}$ of glucose and fructose, respectively. Lactic acid ( $0.32 \mathrm{~g} / \mathrm{L}$ ) was the most important organic compound formed during fermentation, followed by succinic and acetic acids ( 0.08 and $0.05 \mathrm{~g} / \mathrm{L}$, respectively). Lactic acid is an important organic compound for coffee bean fermentation that assists in the coffee pulp acidification without interfering with the final product quality (22). The accentuated production of lactic acid is in agreement with the strong dominance of lactic acid bacteria found in the present study (Fig. 1), resulting in $\mathrm{pH}$ decrease from 5.3 to 4.0 at the end of fermentation (Table 1). The reduction of $\mathrm{pH}$ below 4.5 is a widely used method by coffee producers to determine the end of fermentation of coffee bean during wet processing (23).
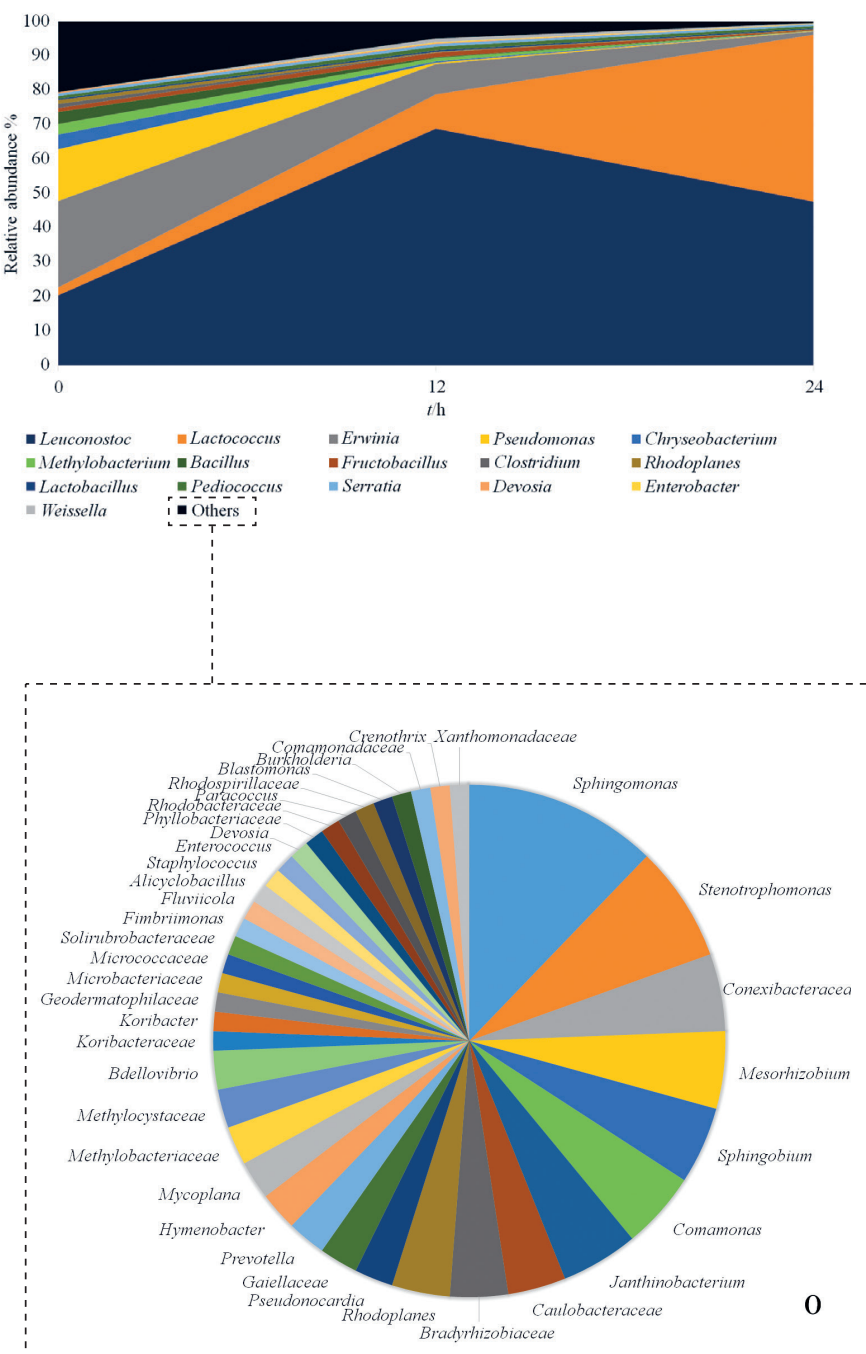

\section{Characteristics of sample sequencing data}

A total of 440524 high-quality sequences of the hypervariable $\mathrm{V} 3$ region of the $16 \mathrm{~S}$ rRNA gene region were obtained after trimming on the Illumina MiSeq sequencing, with an

Table 1. Concentration of sugars, organic acids and ethanol during coffee bean fermentation

\begin{tabular}{cccc} 
& \multicolumn{3}{c}{$t($ fermentation $) / \mathrm{h}$} \\
\cline { 2 - 4 } Compound & 0 & \multicolumn{3}{c}{$\gamma /(\mathrm{g} / \mathrm{L})$} \\
\cline { 2 - 4 } & \multicolumn{3}{c}{24} \\
Glucose & $(2.7 \pm 0.3)^{\mathrm{a}}$ & $(5.5 \pm 0.3)^{\mathrm{b}}$ & $(3.3 \pm 0.1)^{\mathrm{a}}$ \\
Fructose & $(3.4 \pm 0.3)^{\mathrm{a}}$ & $(7.33 \pm 0.09)^{\mathrm{b}}$ & $(4.5 \pm 0.2)^{\mathrm{c}}$ \\
Succinic acid & n.d. & n.d. & $0.08 \pm 0.01$ \\
Lactic acid & n.d. & n.d. & $0.32 \pm 0.01$ \\
Acetic acid & n.d. & n.d. & $0.051 \pm 0.004$ \\
Propionic acid & n.d. & n.d. & n.d. \\
Ethanol & n.d. & n.d. & n.d. \\
pH & $(5.30 \pm 0.03)^{\mathrm{a}}$ & $(4.90 \pm 0.05)^{\mathrm{a}}$ & $(4.00 \pm 0.10)^{\mathrm{b}}$
\end{tabular}

Mean values of triplicate measurements in each row with the same letter are not significantly different $(p>0.05)$ from one another using Duncan's test (mean value \pm standard variation); n.d.=not detected

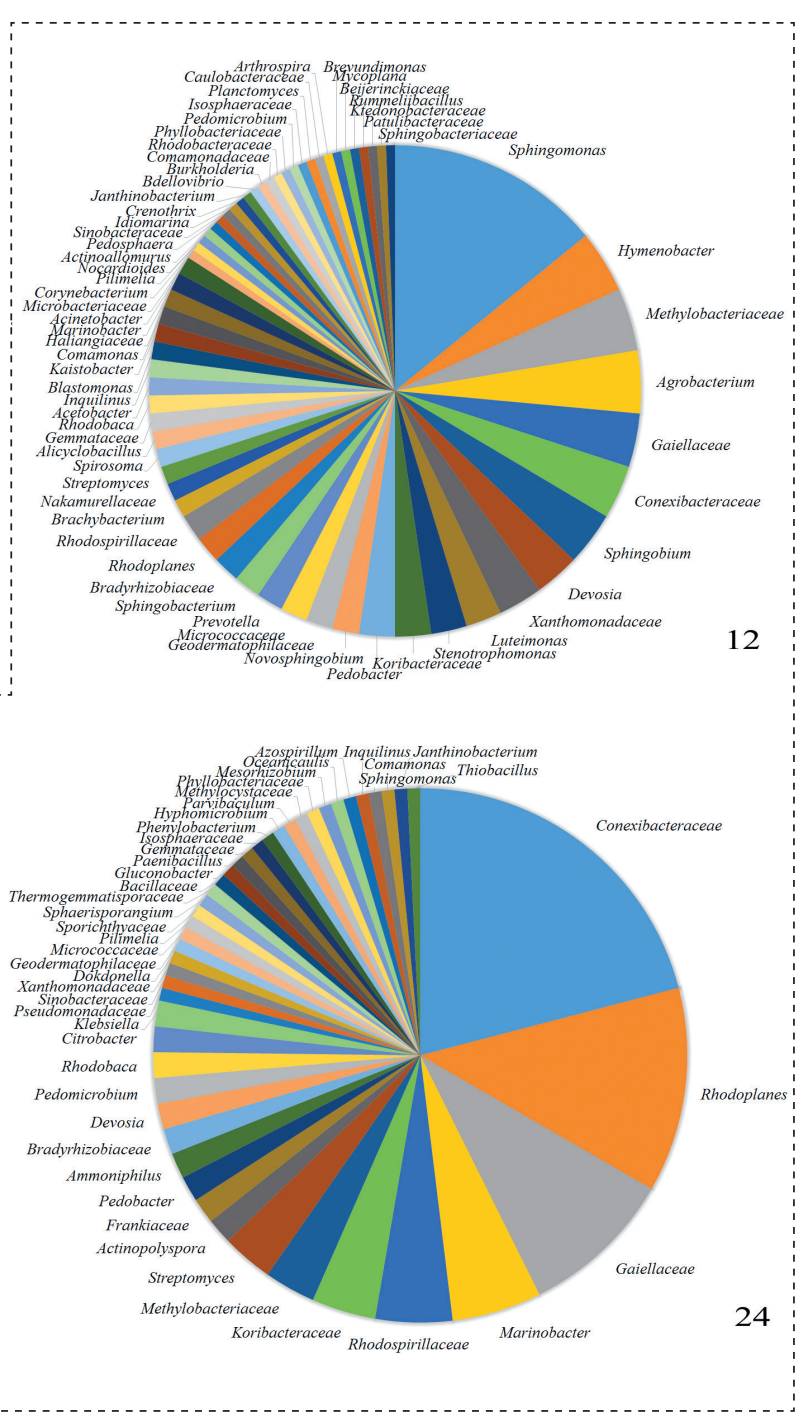

Fig. 1. Bacterial community composition and dynamics during Brazilian coffee bean fermentation as shown by high-throughput rRNA gene sequencing 
average length of $250 \mathrm{bp}$. A great coverage was obtained in all samples as demonstrated by the rarefaction curves (Fig. 2).

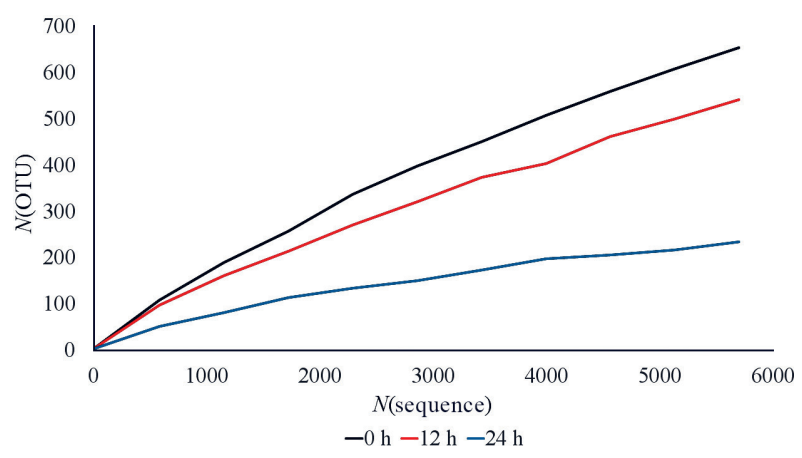

Fig. 2. Rarefaction analysis of the genera found at 0,12 and $24 \mathrm{~h}$ of coffee bean fermentation. OTU=operational taxonomic unit

\section{Bacterial diversity and dynamics}

Studies evaluating the microbiology of coffee fermentation have been performed over the last 100 years in several coffee-producing regions, evidencing the dominant species during the post-harvest processing (6,7,24-29). On average, nine bacterial genera had been reported in previous studies using culture-dependent methods $(7,15,30-33)$. Our work demonstrates that these findings are an underestimate, since over eighty genera of bacteria have been identified by HTS. High frequency and abundance of readings corresponding to Proteobacteria (e.g. Erwinia, Pseudomonas and Methylobacterium) and Firmicutes (e.g. Bacillus, Fructobacillus, Leuconostoc and Lactococcus) were observed. The possible habitat origins of these microbial groups are: human contact, e.g. Pseudomonas sp., Enterobacter, Erwinia and Actinobacteria (34), soil or aerial parts of coffee plants, e.g. Mesorhizobium, Methylobacterium, Stentrophomonas, Sphingobium and Sphingomonas (35-37), the water source used for wet processing, e.g. Planctomyces, Luteimonas, Devosia and Brevundimonas (38), and the air surrounding the fermentation tank, e.g. Janthinobacterium, Pedobacter, Burkholderia and Kaistobacter (39). These findings indicate the need for a program of research to understand the microbial ecology origin of coffee cherries and processing sites.

The rich and complex bacterial diversity revealed in this study demonstrates the potential of coffee terroir as a source of microorganism species with biotechnological application. An example is the first report of the presence of Fructobacillus in coffee fermentation. This LAB group has a unique biochemical metabolism when compared to other $L A B$, having preference for fructose consumption and the necessity of an elector acceptor when in presence of glucose (40). Fructobacillus microorganisms were found in gastrointestinal tracts of insects feeding on fructose-rich diet and presented symbiotic interactions with its hosts $(41,42)$. A survey of previous studies demonstrates significant amount of residual pulp fructose at the end of coffee fermentations conducted under field conditions (20), even by using selected starter cultures $(4,15,43)$. With these findings, the isolation and further implementation of Fructobacillus may assist in the fructose metabolism, contributing to drying of coffee beans.

Bacterial composition and dynamics shown in Fig. 1 reveal that, despite the presence of a high bacterial diversity associated with coffee fermentation environment, several microorganisms are suppressed by the growth and dominance of LAB group. Reads assigned to LAB genera, including $L a C$ tobacillus, Pediococcus, Enterococcus, Leuconostoc, Lactococcus and Fructobacillus, corresponded to $26.32 \%$ at the start of the process and reached a total of $97.59 \%$ of the total operational taxonomic units (OTU) at $24 \mathrm{~h}$. The high availability of fermentable sugars coupled with the low presence of dissolved oxygen creates a propitious environment for the rapid growth and colonization of these species, which promote an efficient conversion of sugars into mainly lactic acid (44).

Within the LAB group, Leuconostoc and Lactococcus shared dominance. Species of Leuconostoc, such as L. mesenteroides, L. pseudomesenteroides and L. citreum, have already been reported as dominant $L A B$ in coffee fermentations performed in Mexico, Colombia, India and Taiwan $(6,45,46)$, while Lactococcus species dominates coffee fermentations performed in Taiwan and Brazil $(45,47)$. Co-dominance of LAB enables the production of a wide range of organic compounds (e.g. acetate, acetaldehyde, ethanol, short-chain fatty acids) by heterofermentation (e.g. Leuconostoc sp.) and a high production of lactic acid through homofermentation (e.g. Lactococcus sp.), which promotes yeast growth and reduces the prevalence of spoilage microorganisms.

\section{CONCLUSION}

The present study suggests that most of bacterial species involved in the coffee bean fermentation have not been determined. High-throughput 16S rRNA gene sequencing analysis allowed us to reveal in depth the presence of several microbial groups with potential applications. A strong dominance of LAB was confirmed, proving the good adaptation of this microbial group to coffee fermentation environment. Further studies should focus on the isolation of some microbial groups first reported in this study for potential biotechnological applications.

\section{ACKNOWLEDGEMENTS}

The authors thank Conselho Nacional de Desenvolvimento Científico e Tecnológico do Brasil (CNPq) for the research scholarship.

\section{REFERENCES}

1. Lee LW, Cheong MW, Curran P, Yu B, Liu SQ. Coffee fermentation and flavor - An intricate and delicate relationship. Food Chem. 2015;185:182-91.

https://doi.org/10.1016/j.foodchem.2015.03.124

2. Total production by all exporting countries. London, UK: International Coffee Organization (ICO); 2017. Available 
from: http://www.ico.org/historical/1990\%20onwards/ PDF/1a-total-production.pdf.

3. Avallone S, Brillouet JM, Guyot B, Olguin E, Guiraud JP. Involvement of pectinolytic micro-organisms in coffee fermentation. Int J Food Sci Technol. 2002;37:191-8. https://doi.org/10.1046/j.1365-2621.2002.00556.x

4. Evangelista SR, Silva CF, Pedrozo da Cruz Miguel MG, de Souza Cordeiro C, Marques Pinheiro AC, Ferreira Duarte W, Freitas Schwan R. Improvement of coffee beverage quality by using selected yeasts strains during the fermentation in dry process. Food Res Int. 2014;61:183-95. https://doi.org/10.1016/j.foodres.2013.11.033

5. Silva CF, Marques Vilela D, de Souza Cordeiro C, Ferreira Duarte W, Ribeiro Dias D, Freitas Schwan R. Evaluation of a potential starter culture for enhance quality of coffee fermentation. World J Microbiol Biotechnol. 2013;29:235-47. https://doi.org/10.1007/s11274-012-1175-2

6. Avallone S, Guyot B, Brillouet JM, Olguin E, Guiraud JP. Microbiological and biochemical study of coffee fermentation. Curr Microbiol. 2001;42:252-6. https://doi.org/10.1007/s002840110213

7. de Melo Pereira GV, Thomaz Soccol V, Pandey A, Bianchi Pedroni Medeiros A, Rodrigues Andrade Lara JM, Gollo $A L$, Soccol CR. Isolation, selection and evaluation of yeasts for use in fermentation of coffee beans by the wet process. Int J Food Microbiol. 2014;188:60-6. https://doi.org/10.1016/j.ijfoodmicro.2014.07.008

8. Mussatto SI, Machado EMS, Martins S, Teixeira JA. Production, composition, and application of coffee and its industrial residues. Food Bioprocess Technol. 2011;4:661-72. https://doi.org/10.1007/s11947-011-0565-z

9. Cocolin L, Ercolini D. Zooming into food-associated microbial consortia: A 'cultural' evolution. Curr Opin Food Sci. 2015;2:43-50.

https://doi.org/10.1016/j.cofs.2015.01.003

10. Doyle CJ, Gleeson D, O'Toole PW, Cotter PD. Highthroughput metataxonomic characterization of the raw milk microbiota identifies changes reflecting lactation stage and storage conditions. Int J Food Microbiol. 2017;255:1-6.

https://doi.org/10.1016/j.ijfoodmicro.2017.05.019

11. Garofalo C, Osimani A, Milanović V, Taccari M, Cardinali F, Aquilanti $\mathrm{L}$, et al. The microbiota of marketed processed edible insects as revealed by high-throughput sequencing. Food Microbiol. 2017;62:15-22.

https://doi.org/10.1016/j.fm.2016.09.012

12. Połka J, Rebecchi A, Pisacane V, Morelli L, Puglisi E. Bacterial diversity in typical Italian salami at different ripening stages as revealed by high-throughput sequencing of $16 \mathrm{~S}$ rRNA amplicons. Food Microbiol. 2015;46:342-56. https://doi.org/10.1016/j.fm.2014.08.023

13. Yang L, Yang HL, Tu ZC, Wang XI. High-throughput sequencing of microbial community diversity and dynamics during douchi fermentation. PLoS ONE. 2016;11:e0168166. https://doi.org/10.1371/journal.pone.0168166
14. Vasileiadis S, Puglisi E, Arena M, Cappa F, Cocconcelli PS, Trevisan M. Soil bacterial diversity screening using single $16 \mathrm{~S}$ rRNA gene $\mathrm{V}$ regions coupled with multi-million read generating sequencing technologies. PLoS ONE. 2012; 7:e42671. https://doi.org/10.1371/journal.pone.0042671

15. de Melo Pereira GV, Neto E, Soccol VT, Bianchi Pedroni Medeiros A, Lorenci Woiciechowski A, Soccol CR. Conducting starter culture-controlled fermentations of coffee beans during on-farm wet processing: Growth, metabolic analyses and sensorial effects. Food Res Int. 2015;75:348-56. https://doi.org/10.1016/j.foodres.2015.06.027

16. Caporaso JG, Lauber CL, Walters WA, Berg-Lyons D, Huntley J, Fierer N, et al. Ultra-high-throughput microbial community analysis on the Illumina HiSeq and MiSeq platforms. ISME J. 2012;6:1621-4. https://doi.org/10.1038/ismej.2012.8

17. Caporaso JG, Kuczynski J, Stombaugh J, Bittinger K, Bushman FD, Costello EK, et al. QIIME allows analysis of highthroughput community sequencing data. Nat Methods. 2010;7:335-6. https://doi.org/10.1038/nmeth.f.303

18. Edgar RC. Search and clustering orders of magnitude faster than BLAST. Bioinformatics. 2010;26:2460-1. https://doi.org/10.1093/bioinformatics/btq461

19. Quast C, Pruesse E, Yilmaz P, Gerken, J, Schweer T, Yarza $P$, et al. The SILVA ribosomal RNA gene database project: Improved data processing and web-based tools. Nucleic Acids Res. 2013;41:D590-6. https://doi.org/10.1093/nar/gks1219

20. de Carvalho Neto DP, de Melo Pereira GV, Tanobe VOA, Soccol VT, da Silva BJG, Rodrigues C, Soccol CR. Yeast diversity and physicochemical characteristics associated with coffee bean fermentation from the Brazilian Cerrado Mineiro region. Fermentation. 2017;3:1-11. https://doi.org/10.3390/fermentation3010011

21. Teixeira Magalhães K, de Melo Pereira GV, Ribeiro Dias D, Freitas Schwan R. Microbial communities and chemical changes during fermentation of sugary Brazilian kefir. World J Microbiol Biotechnol. 2010;26:1241-50. https://doi.org/10.1007/s11274-009-0294-x

22. de Melo Pereira GV, Soccol VT, Brar SK, Neto E, Soccol CR. Microbial ecology and starter culture technology in coffee processing. Crit Rev Food Sci Nutr. 2017;57:2775-88. https://doi.org/10.1080/10408398.2015.1067759

23. de Melo Pereira GV, de Carvalho Neto DP, Bianchi Pedroni Medeiros A, Soccol VT, Neto E, Woiciechowski AL, Soccol CR. Potential of lactic acid bacteria to improve the fermentation and quality of coffee during on-farm processing. Int J Food Sci Technol. 2016; 51:1689-95. https://doi.org/10.1111/ijfs.13142

24. Agate AD, Bhat JV. Role of pectinolytic yeasts in the degradation of mucilage layer of Coffea robusta cherries. Appl Microbiol. 1966;14:256-60. 
25. Frank HA, Lum NA, Delacruz AS. Bacteria responsible for mucilage-layer decomposition in Kona coffee cherries. Appl Microbiol. 1965;13:201-7.

26. Masoud W, Cesar LB, Jespersen L, Jakobsen M. Yeast involved in fermentation of Coffea arabica in East Africa determined by genotyping and by direct denaturating gradient gel electrophoresis. Yeast. 2004;21:549-56. https://doi.org/10.1002/yea.1124

27. Pederson CS, Breed RS. Fermentation of coffee. Food Res. 1946;11:99-106. https://doi.org/10.1111/j.1365-2621.1946.tb16331.x

28. Ferreira Silva C, Freitas Schwan R, Sousa Dias E, Wheals $A E$. Microbial diversity during maturation and natural processing of coffee cherries of Coffea arabica in Brazil. Int J Food Microbiol. 2000;60:251-60. https://doi.org/10.1016/S0168-1605(00)00315-9

29. Silva CF, Batista LR, Abreu LM, Sousa Dias E, Freitas Schwan R. Succession of bacterial and fungal communities during natural coffee (Coffea arabica) fermentation. Food Microbiol. 2008;25:951-7. https://doi.org/10.1016/j.fm.2008.07.003

30. Evangelista SR, da Cruz Pedroso Miguel MG, Ferreira Silva C, Marques Pinheiro AC, Freitas Schwan R. Microbiological diversity associated with the spontaneous wet method of coffee fermentation. Int J Food Microbiol. 2015;210:102-12. https://doi.org/10.1016/j.jjfoodmicro.2015.06.008

31. Feng X, Dong H, Yang P, Yang R, Lu J, Lv J, Sheng J. Culturedependent and-independent methods to investigate the predominant microorganisms associated with wet processed coffee. Curr Microbiol. 2016;73:190-5. https://doi.org/10.1007/s00284-016-1047-3

32. Hamdouche Y, Meile JC, Nganou DN, Durand N, Teyssier C, Montet D. Discrimination of post-harvest coffee processing methods by microbial ecology analyses. Food Control. 2016;65:112-20. https://doi.org/10.1016/j.foodcont.2016.01.022

33. Nasanit R, Satayawut K. Microbiological study during coffee fermentation of Coffea arabica var. chiangmai 80 in Thailand. Kasetsart J (Nat Sci.) 2015;49:32-41.

34. Grice EA, Kong HH, Renaud G, Young AC, NISC Comparative Sequencing Program, Bouffard GG, et al. A diversity profile of the human skin microbiota. Genome Res. 2008;18:1043-50. https://doi.org/10.1101/gr.075549.107

35. Carrell AA, Frank AC. Pinus flexilis and Picea engelmannii share a simple and consistent needle endophyte microbiota with a potential role in nitrogen fixation. Front $\mathrm{Mi}-$ crobiol. 2014;5:333.

https://doi.org/10.3389/fmicb.2014.00333

36. Ma L, Cao YH, Cheng MH, Huang Y, Mo MH, Wang Y, et al. Phylogenetic diversity of bacterial endophytes of Panax notoginseng with antagonistic characteristics towards pathogens of root-rot disease complex. Antonie van Leeuwenhoek. 2013;103:299-312.

https://doi.org/10.1007/s10482-012-9810-3
37. Vega FE, Pava-Piroll M, Posada F, Buyer JS. Endophytic bacteria in Coffea arabica L. J Basic Microbiol. 2005;45:371-80. https://doi.org/10.1002/jobm.200410551

38. Martiny AC, Albrechtsen HJ, Arvin E, Molin S. Identification of bacteria in biofilm and bulk water samples from a nonchlorinated model drinking water distribution system: Detection of a large nitrite-oxidizing population associated with Nitrospira spp. Appl Environ Microbiol. 2005;71:8611-7.

https://doi.org/10.1128/AEM.71.12.8611-8617.2005

39. Fahlgren C, Hangström A, Nilsson D, Zweifel UL. Annual variations in the diversity, viability, and origin of airborne bacteria. Appl Environ Microbiol. 2010;76:3015-25.

https://doi.org/10.1128/AEM.02092-09

40. Endo A, Dicks LMT. The genus Fructobacillus. In: Holzapfel WH, Wood BJB, editors. Lactic acid bacteria: Biodiversity and taxonomy. London, UK: John Wiley \& Sons; 2014. pp. 381-9.

https://doi.org/10.1002/9781118655252.ch22

41. Janashia I, Choiset $\mathrm{Y}$, Rabesona H, Hwanhlem N, Bakuradze $\mathrm{N}$, Chanishvili N, Haertlé T. Protection of honeybee Apis mellifera by its endogenous and exogenous lactic flora against bacterial infections. Ann Agr Sci. 2016;14:17781. https://doi.org/10.1016/j.aasci.2016.07.002

42. Janashia I, Alaux C. Specific immune stimulation by endogenous bacteria in honey bees (Hymenoptera: Apidae). J Econ Entomol. 2016;1-4. https://doi.org/10.1093/jee/tow065

43. Evangelista SR, da Cruz Pedrozo Miguel MG, de Souza Cordeiro C, Ferreira Silva C, Marques Pinheiro AC, Freitas Schwan R. Inoculation of starter cultures in a semi-dry coffee (Coffea arabica) fermentation process. Food Microbiol. 2014;44:87-95.

https://doi.org/10.1016/j.fm.2014.05.013

44. Endo A, Dicks LMT. Physiology of the LAB. In: Holzapfel WH, Wood BJB, editors. Lactic acid bacteria: Biodiversity and taxonomy. London, UK: John Wiley \& Sons; 2014. pp. 13-30.

https://doi.org/10.1002/9781118655252.ch22

45. Leong KH, Chen YS, Pan SF, Chen JJ, Wu HC, Chang YC, Yanagida F. Diversity of lactic acid bacteria associated with fresh coffee cherries in Taiwan. Curr Microbiol. 2014;68:440-7. https://doi.org/10.1007/s00284-013-0495-2

46. Velmourougane K. Impact of natural fermentation on physicochemical, microbiological and cup quality characteristics of Arabica and Robusta coffee. Proc Natl Acad Sci. 2013;8:233-9.s https://doi.org/10.1007/s40011-012-0130-1

47. Vilela DM, de Melo Pereira GV, Ferreira Silva C, Batista LR, Freitas Schwan R. Molecular ecology and polyphasic characterization of the microbiota associated with semi-dry processed coffee (Coffea arabica L.). Food Microbiol. 2010;27:1128-35. https://doi.org/10.1016/j.fm.2010.07.024 